\title{
Die Tora as die sleutel tot die verstaan van die verhouding tussen God en mens: 'n Verbondsmatig-Christologiese perspektief
}

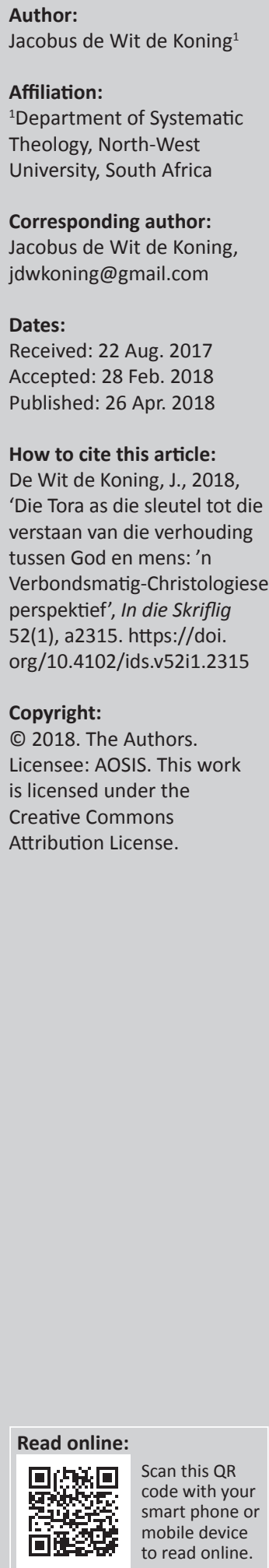

\begin{abstract}
The Torah as the key to the understanding of the relationship between God and man: A covenantal-Christological perspective. This article indicates that the understanding and handling of the law of Moses, as found in the federal theology of the Westminster Confession of Faith, can easily lead to the relationship between God and man being understood as a legal relationship in which the covenant acquires the character of a bilateral contract. This article questions this view after looking at the nature of Moses' law as Torah. Such understanding indicates the inextricable unity between law and covenant. As a next step, it is therefore indicated that Jesus Christ fulfils this Torah to such an extent that it can be said that he himself takes on the function of the Torah in the life of the Christian. Indeed, Jesus is the Torah under the new covenant. In conclusion, the implications for the life of the New Testament Christian are briefly touched upon.
\end{abstract}

\section{Inleiding}

In die geskiedenis van die kerk het daar na die reformasie 'n vorm van Calvinisme ontstaan wat 'n sentrale plek gee aan die konsep van die verbond (foedus, pactum, testamentum) en wat tussen verskeie verbonde (foedera) onderskei wanneer daar gepraat word oor God se verhouding met die wêreld. Spesifiek word daar verwys na 'n 'verbond van werke' (foedus operum of foedus naturale natuurverbond) en 'n 'verbond van genade' (foedus gratiae). Hierdie vorm van Calvinisme wat as 'federale teologie' (afgelei van Latyn foedus) beskryf kan word omdat dit die verbond as ordeningsprinsipe vir die hele teologie hanteer, vind uiteindelik neerslag in die Westminster Confession of Faith (WCF). Dit bely dat die 'morele wet' ten alle tye onveranderd die standaard is vir die lewe van God se volk. Christus en die apostels herbevestig die gesag van die morele wet en wys vir ons die ware betekenis van die onveranderde woorde van die morele wet. Die Dekaloog is die hoogste standaard vir moraliteit. Tog het die burgerlike sowel as die seremoniële wette geen bindende gesag meer oor gelowiges ná die koms van Christus nie (VanGemeren 1996:13-58).

Die vraag is natuurlik of hierdie antwoord reg laat geskied aan die geheelboodskap van die Skrif, veral aan die Bybels-teologiese fokus op Christus as God se hoogste openbaring. Vir gereformeerdes wat hiermee erns maak en vir wie die verbond belangrik is, is daar dus 'n onontkombare vraag: Hoe moet 'n verbondsmatige teologiese beskouing van die wet van Moses ná die koms van Christus daar uitsien as dit Skrifgetrou wil wees en in die geheelboodskap van die Skrif wil inpas?

In hierdie artikel is die bepaalde problematiek wat verheldering en uiteindelik 'n oplossing vereis dus die volgende: 'Hoe moet die wet van Moses gesien word in die bedeling ná Christus?'

\section{Die wet van Moses en die werkverbond: Vanaf Reformasie tot Westminster Confession of Faith}

Om die vraag na 'n Skrifgetroue verbondsmatige beskouing van die wet van Moses ná die koms van Christus te beantwoord, moet daar eerstens gekyk word na die twyfelagtige teologiese ontwikkeling van die werkverbondsleer wat na die reformasie tot stand gekom het en uiteindelik neerslag vind in die WCF. Die siening van die wet wat hieruit na vore kom, sal dan uiteindelik nie net aan die reformatore se siening gemeet word nie, maar aan die Skrif self.

Dit is belangrik om te onthou dat die Hervormers grootliks met die wet van Moses as ' $n$ teologiese realiteit (Wet teenoor Evangelie) gewerk het en nie soseer as 'n historiese realiteit nie (Inst. 2.7.9; Luther 1856:520-536; LW 26.80 e.v.). 
Hierdie benadering beïnvloed dan ook hulle eksegese. Verder hanteer hulle ook nog nie die wet en verbond op so 'n wyse dat daar van 'n pre-lapsariese (voor sondeval) 'werkverbond' sprake is nie. Vir Luther (LW 25.275) is dit onmoontlik, omdat die wet met sy negatiewe konnotasie nooit gegee kon word vir die bereiking van die goeie nie; net deur geloof is dít moontlik (vgl. Forde 1997:57).

Calvyn (Inst. 2.10.4) weer, gaan nie sover om 'n 'werkverbond' te bely nie (Hesselink 1997:83), aangesien die wet vir hom juis uit die verbond van genade vloei. In Calvyn se wetsbeskouing word wel sterk Bybels-teologiese tendense gevind. Die wet en Christus word by tye byna uitruilbaar gebruik met die gevolg dat Christus die wet van Moses vir die gelowige word. Christus (Inst. 3.6.3) sowel as die wet van Moses (Inst. 2.7.6) word afwisselend as riglyn vir die Christelike lewe geïdentifiseer. Tog word daar steeds nie pre-lapsaries oor die verhouding tussen Christus en die wet van Moses gedink nie.

Uiteindelik is dit Bullinger wat die Reformasie en die Patristiek se beklemtoning verenig en die teologiese idee van verbond (foedus) formuleer (McCoy \& Baker 1991:17). Ursinus word in 1562 die eerste teoloog wat in sy Kategismus onderskei tussen 'n foedus naturale [natuurverbond] wat by die skepping van die mens tussen God en die mens tot stand gekom het, en die foedus gratia [genadeverbond] wat ná die sondeval in werking tree. Hy gebruik dus 'n pre-lapsariese verbond as ' $n$ manier om Genesis 1 tot 3 se verhaal van die mens vóór die sondeval te interpreteer in teenstelling met Calvyn, Zwingli, Bullinger en die ander Hervormers wat net werk met die genadeverbond as ' $n$ post-lapsariese verbond wat met sondaars ná die sondeval gesluit is. Vir die eerste keer in die gereformeerde tradisie is die konsep foedus gebruik om die skepping en menslike bestaan vóór die sondeval te interpreteer. Die konsep van 'n foedus naturale, of foedus creationis was egter nog nie ' $n$ koördinerende beginsel in hulle teologie nie (Torrance 1994:21). Voor die einde van die sestiende eeu verkry dit so 'n oorheersende funksie en in 1558 publiseer die Puritein, Dudley Fenner sy Sacra Theologia wat die eerste werk is waarvan ons weet wat die term covenant of works (foedus operum) of the covenant of law gebruik (Torrance 1994:24). In 'n gemoderniseerde Engelse weergawe lees Fenner (1613) se eie woorde só:

Righteousness thus set forth in his several parts and branches, has of God's free goodness a reward belonging to it, (whereupon the same called the Law, or covenant of works;) as contrariwise a punishment in his Justice to those that sin against it: both more or less, as the righteousness or sin abounds. (Sacra Theologia, xvi)

Dit is die eerste teologiese werk wat verskeie Ou- en NuweTestamentiese gedeeltes omvattend gebruik ter ondersteuning van die konsep van 'n pre-lapsariese verbond (Karlberg 1980:23; McCoy \& Baker 1991:40; Weir 1990:147).

Uiteindelik vind ons die volgende in federale teologie soos dit neerslag vind in Baptiste (die 1689 Baptist Confession of Faith) sowel as Paedo Baptiste (die WCF). Ons vind die belydenis dat die Dekaloog of 'morele wet' wat God by Sinaï aan Israel gegee het, dieselfde is as die werkverbond wat inhoud betref. Aan Israel is dit egter as 'n perfekte riglyn vir die lewe van geregtigheid gegee. Hierdie 'morele' of 'sedewet' is steeds ook die riglyn vir die Christen se dankbaarheidslewe (WCF 2010, 19.2) Benewens hierdie normatiewe (derde) gebruik, vervul die sedewet ook 'n burgerlike (eerste gebruik) funksie en 'n pedagogiese (tweede gebruik) funksie in hierdie bedeling. In die breë is die bedoeling van die genadeverbond dat aan die eise van die werkverbond voldoen moet word. Waar die sondaar dit nie meer self kon doen nie, het Christus gekom om dit in sy plek te doen. So is die genadeverbond eintlik daar om die oorspronklike verbond van God met die mens, naamlik die werkverbond met sy eis van wetsonderhouding te vervul (Torrance 1994:32).

Die werkverbond raak dus die primêre standaard waaraan die mens moet voldoen om God te behaag. Die WCF (2010) skep die indruk dat die model en beeld waarna ons moet beweeg nie Christus is nie, maar die 'law, as a covenant of works' (19.1) wat reeds in Adam se hart geskryf is en steeds '... the perfect rule of righteousness after the Fall' (19.2) is. Dit is natuurlik 'n afwyking van Calvyn wat Christus sien as die model en beeld waartoe God ons wil verander. Hy stel dit kragtig:

En om ons nog beter tot besinning te bring, toon die Skrif ons dat God die Vader, soos Hy ons in sy Gesalfde met Hom versoen het, so in Hom vir ons ' $n$ beeld afgestempel het, en Hy wil hê dat ons daaraan gelykvormig moet word. (Inst. 3.6.3).

Kommerwekkend is ook die feit dat genade in federale teologie eers ná die sondeval ter sprake kom. Voor die sondeval was die mens in die staat van 'n 'natuurlik onafhanklike' en het dus nie genade nodig gehad nie. Hierteenoor aanvaar Calvyn sowel as Luther dat Adam voor die sondeval in alles van God afhanklik was.

Vir Luther is dit ondenkbaar dat Adam en Eva deur goeie werke uiteindelik gered kon word. In tesis 15 van sy Heidelbergse Disputasie van 1518 (Forde 1997), maak Luther dit byvoorbeeld duidelik dat die mens, selfs vóór die sondeval, nie 'n vrye wil gehad het om in 'n aktiewe kapasiteit onskuldig te bly nie. Hy kon dit net doen in 'n passiewe kapasiteit. Adam en Eva was dus nie in die staat van onskuld gehou deur hulle eie krag nie, maar deur krag van buite. Hulle was skepsels wat deur geloof geleef het en nie in hulle eie krag nie, maar deur op hulle Skepper te vertrou (WA 1.350-374). As ons wel sê dat Adam voor die sondeval die aktiewe kapasiteit gehad het om self te vorder, moet ons natuurlik ook self kan vorder nadat ons onsself in die staat van genade bevind. Dit wou Luther natuurlik onder geen omstandighede hê nie, want dit sou weereens beteken dat dit wat sleg is, goed genoem word (Forde 1997:57).

Calvyn, in aansluiting by Augustinus, stel die mens se nood aan genade só:

Die wet is vir hierdie doel gegee om van 'n magtige mens ' $n$ geringe te maak; om vir jou aan te toon dat jy uit jou eie geen krag het om geregtigheid te bereik nie, maar dat jy hulpeloos, onwaardig en behoeftig jou toevlug tot Sy Genade moet neem. (Inst. 2.7.9) 
Juis wanneer dit in gedagte gehou word, is dit nie vreemd dat Calvyn nog nie so ver gaan as om 'n 'werkverbond' te onderskryf nie. Hoewel Calvyn alreeds aanvaar het dat die verhouding waarin Adam voor die sondeval tot God gestaan het ' $n$ verbondsverhouding was, sien hy dit nog nie as ' $n$ tweede verbond naas die verbond van genade nie (Jonker 1989:84). Calvyn gebruik nooit die woord foedus om die skepping vóór die sondeval te beskryf nie. Hy beperk die woord tot die verbond van genade wat post-lapsaries (na die sondeval) met sondaars gemaak is. Hy leer ook nooit die konsep van 'n foedus naturale of 'n verbond van werke (foedus operum) nie (vgl. McNeil 1946:3). Calvyn (Inst. 4.20.14-16) verwys hoogstens in die verbygaan na 'natuurlike wet' soos onderskei deur die gewete wanneer hy Romeine 1:19-22 en 2:14-15 bespreek.

Die toestand van die mens voor die sondeval kan in die lig van bogenoemde dus reeds as 'n staat van genade beskryf word (Le Roux 1991:55). Volgens federalisme het genade 'n 'herstel-funksie'. Anders gestel: genade is nie primêr nie, maar sekondêr. Ná die oordeel sal die mens herstel word tot die posisie waarin hy voor die sondeval was (met sekere verskille). Jeremia 31:31-34 word gesien as 'n belofte om terug te keer na die verbondstaat soos voor die sondeval (Weir 1990:6-7). Wat prioriteit betref, is Wet dus hoër as genade, want dit gaan logies genade vooraf (Bell 1985:198). Die groot probleem is dat hierdie posisie maklik daartoe kan lei dat Wet gesien word as belangriker as Evangelie omdat dit, in werklikheid, as die sleutel vir die verstaan van die verhouding tussen God en die mens hanteer word. In die lig van bogenoemde word die indruk deur die Federale skema geskep dat die evangelie, logies gesproke, net 'n instrument word om die mens wat nie meer deel van die werkverbond is nie, weer in staat te stel om deur genade die wet te vervul. Kortliks kan dus gesê word dat in die federale teologie se hantering van die wet en die verbond, die wet voorrang bo genade het.

Die logiese uitvloeisel van die federale sisteem kan daartoe lei dat die verhouding tussen God en die mens nie primêr as 'n genadeverhouding gesien word soos deur Luther en Calvyn nie, maar as 'n regsverhouding. Die eerste en mees fundamentele verhouding tussen God en die mens word dus wetlik gesien en nie in terme van genade nie (Rolston 1972:133). Hiermee het die karakter van verbond radikaal verander. Dit is nie meer monopleuries nie, maar dra feitlik uitsluitlik die karakter van 'n bilaterale kontrak. Die hele bedoeling van die benaming werkverbond is dan ook om hierdie kontrak-karakter uit te lig. Die basiese verhouding tussen God en die mens word 'n verhouding van werke waarin die mens deur sy onderhouding van die wet die ewige lewe moes kry. Indien dit nie die bedoeling was nie, kon ander benamings wat in omloop was (soos 'oorspronklike', 'Adamitiese', 'natuur-' of 'skeppingsverbond') behou word. Die benaming werkverbond is juis gekies om uitdrukking daaraan te gee dat die mens slegs langs die weg van gehoorsaamheid aan die wet gered kan word. 'n Mens sou kon redeneer dat die woord verbond, in teenstelling met die woord kontrak, tog 'n persoonlike konnotasie van 'n lewende gemeenskap het. Torrance (1994:32) wys egter oortuigend daarop dat 'verbond' by federale teoloë ná Calvyn as 'n wedersydse bilaterale kontrak gesien is waar die verantwoordelikheid vir die vervulling van die verbond by die mens berus. Die ideaal in hierdie skema is dus die 'oorspronklike' verhouding tussen God en die mens soos in die paradys waar die mens deur sy werke sy bestaan regverdig.

Dit blyk dat die leer van die werkverbond deur die jare reaksie uitgelok het onder teoloë juis omdat die benaming werk onmiddellik op ' $n$ teenstrydigheid met ander beklemtonings van die gereformeerde leer dui. Hier kan gedink word aan Barth (CD 41.54) wat Jesus Christus sien as '... the content of the eternal will of God, the eternal covenant between God and man'. Hy is geensins alleen in sy kritiek nie. Murray (1977:47-59) wat sterk uit die Skots-Puriteinse tradisie werk sowel as Nederlandse teoloë soos Bavinck (1922:110) en Berkouwer (1971:207) lug hulle besware hierteen. In Suid-Afrika is dit veral Jonker (1989:193, 195) en König (1969:245, 246) wat verkies om nie van 'n werkverbond te praat nie.

Aangesien die invloed van die federale teologie via die belydenisskrifte steeds sterk figureer in die gereformeerde wêreld, is dit noodsaaklik om te kyk of navorsing wat die aard en betekenis van die wet van Moses betref, nie vereis dat gereformeerdes 'n nuwe, verbondsmatige antwoord op die vraag na die siening en hantering van die wet van Moses ná die koms Christus moet gee nie. Só 'n antwoord moet ontkom aan die geneigdheid om die verhouding tussen God en die mens as ' $n$ regsverhouding in plaas van ' $n$ genadeverhouding te beskryf. Hierdie siening van die verhouding tussen God en die mens lei natuurlik ook tot 'n sekere Godsbeskouing en 'n bepaalde manier van wetsprediking. Dit beïnvloed ook die aksente wat in regverdigmaking deur die geloof geplaas word en natuurlik die siening van wat die riglyn vir die Christen se dankbaarheidslewe behoort te wees. Dit alles vra vir 'n korrektief. Ten diepste moet hierdie korrektief op federale teologie 'n antwoord bied op die vraag na die sleutel tot die verstaan van die verhouding tussen God en die mens.

\section{Die bybelse korrektief op die federale verstaan van die wet: Die wet van Moses as Tora}

In hierdie afdeling word aangetoon dat die federale teologie se siening van die wet van Moses verskil van die OuTestamentiese navorsingsbevindings oor die aard van die wet van Moses. Ten diepste word aangedui dat wet in die $\mathrm{Ou}$ Testament as Tora verstaan moet word. Om te verstaan wat Tora is, gaan daar eerstens leksikaal na die woord gekyk word. Hierna word aangedui dat Tora altyd onlosmaaklik verbind is aan die verbondsverhaal van Israel. Laastens word aangedui dat die Tora altyd bondgenote oproep tot geloofsen hartsverandering. Hierdie bevindings sal die weg baan na Jesus en die Nuwe Testament.

\section{Die Tora: Leksikaal}

Daar moet met Dumbrell (1984:91) saamgestem word dat die woord Tora veel meer as bloot 'wet' is. Hierdie siening word 
bevestig wanneer daar na die woord self gekyk word. Dit dui hoegenaamd nie op statiese verwagtings wat die geheel van menslike ervaring beheer nie. Die woord Tora kom van die Hebreeuse werkwoord ירָירא w ירָ wat die betekenis het van 'om te gooi' of 'om te skiet'. In die Hiphil stamformasie neem dit die betekenis aan van 'om te onderrig', 'om die rigting aan te dui uit' soos in Eksodus 35:34 en Levitikus 10:11 (vgl. Brown, Driver \& Briggs 1966:435-436; Koehler \& Baumgarten 1958:1023).

Die feit dat die Tora meer as bloot wet is, is duidelik uit die gebruik van die selfstandige naamwoordsvorm van die werkwoord ירָָ in Eksodus 24 in verband met Tora:

Toe sê die HERE vir Moses: Klim op die berg na My toe en vertoef daar, dat Ek jou die kliptafels kan gee en die wet (וְרָהתוֹרָה)

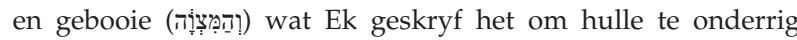

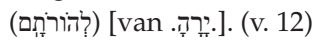

Ander gedeeltes wat duidelik daarop dui dat Tora nie bloot vir wetlike doeleindes gebruik word nie, sluit die volgende in:

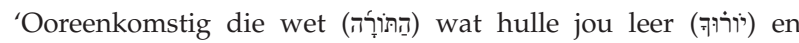
volgens die regspraak wat hulle jou sê, moet jy handel; jy mag nie regs of links afwyk van die uitspraak wat hulle jou te kenne gee nie' (Deut 17:11). '[N]eem jou in ag by die plaag van melaatsheid om baie noukeurig te handel volgens alles wat die Levitiese priesters julle sal leer (יורוּ)' (Deut 24:8).

Die volgende wat ons in Jesaja 2 vind, is baie interessant:

En aan die einde van die dae ... baie volke sal heengaan en sê: Kom laat ons optrek na die berg van die HERE, na die huis van

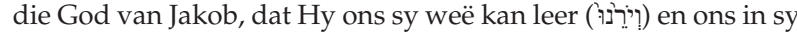
paaie kan wandel. Want uit Sion sal die wet (תוֹרָה) uitgaan en die woord van die HERE uit Jerusalem. (vv. 2-3)

Hierdie laaste gedeelte wat ook die Tora met lering en instruksie verbind, is insiggewend, aangesien hier ' $n$ heenwys is na die Messiaanse era. Die Tora sal in hierdie tyd nie die funksie van blote wetlike verpligtinge hê wat nagekom moet word nie, maar dit sal dien as middel tot rigtinggewing en leiding sodat die volk volgens die wil van die Here kan leef.

\section{Die Tora: Onlosmaaklik verweef met die verbondsverhaal}

Wanneer daar gedink word oor die aard en funksie van die Tora binne die Ou Testament, is dit van kardinale belang om te verstaan dat die wetlike materiaal van die Ou Testament nooit in isolasie voorkom nie. Trouens, die Tora is ingebed in Israel se teologiese geskiedenis. Dit is 'n integrale deel van die storie wat vanaf Genesis 12 tot en met 2 Konings 25 loop. Die Tora word nooit op sigself as 'n losstaande, tydlose universele kode voorgehou wat vir gedrag voorgeskryf word nie. Veel meer word dit voorgehou as deel van die teologiese verhaal wat beskryf hoe God Israel uit Egipte verlos en dan in die beloofde land as sy volk vestig (Hays 2001:25).

Die sleutel tot die kombinasie van Tora en narratief lê in Deuteronomium 1:1 tot 4:43. Die redakteur maak dit duidelik dat Moses onderneem om die Tora te verklaar. Met ander woorde, Moses gaan nou sê wat Tora is (Deut 1:5). Dan vind ons egter dat hy ' $n$ gedeelte van die voorafgaande Pentateug, onder andere die rebellie by Kades-Barnea (Num 13-14), narratief verduidelik. Moses se toespraak bestaan uit interpretasie en kommentaar op die verhaal se betekenis vir sy teenwoordige gehoor. Hy vertel nie net die Tora oor nie, maar verduidelik dit ook. Moses is as ' $t$ ware verteller sowel as prediker. Die resultaat hiervan is dat die narratief self ' $n$ vorm van instruksie is. Meer as dit: dit is betekenisvol dat die redakteur die woord Tora gebruik en nie 'n ander woord vir lering soos byvoorbeeld לַָ in in Deuteronomium 4 vers 1 en 5 nie. In die konteks van dít wat ontvou in Deuteronomium, vorm die verhaal as instruksie 'n bevel aan Moses se luisteraars, aangesien Tora as narratief nie los van die verbondskonteks verstaan kan word nie. Uiteindelik, na die aanhoor van die verhaal, kan daar net op twee maniere gereageer word: 'As gevolg van hierdie verhaal, aanvaar ek die verbond', of 'Ten spyte van hierdie verhaal, verwerp ek die verbond'. Aanvaarding of verwerping sal uiteindelik bepaal of die seën of vloek ontvang word. Die gewigtigheid van die bevel is dus baie duidelik (Mann 1988:146-147).

Daar is nou aangedui dat die wet (Tora) deel uitmaak van die Pentateug-narratief en ingebed is in Israel se eksodus, omswerwinge en oorwinnings. Die implikasie hiervan is duidelik: Die wetsgedeeltes in die Pentateug het dieselfde geldigheid en toepaslikheid as die verhalende gedeeltes en andersom. Dit vorm 'n onlosmaaklike eenheid.

Voortvloeiend hieruit bevestig dit die absolute eenheid tussen die sogenaamde morele, burgerlike en seremoniële wette wat oortuigend deur verskeie teoloë deur die jare onderskei is (Hays 2001:24; Poythress 1991:99-101; Wenham 2003:73).

Dit het nou reeds deurgeskemer dat die Tora as 'n eenheid in 'n verbondskonteks gegee word. Let op Eksodus 19:5: 'As julle dan nou terdeë na my stem luister en my verbond hou, sal julle my eiendom uit al die volke wees, want die hele aarde is myne.' Die volk stem in om die voorwaardes van die verbond na te kom en antwoord: '... Al die woorde wat die HERE gespreek het, sal ons doen.' Hierdie ooreenkoms word deur Moses met bloed beseël:

‘Toe neem Moses die bloed en gooi dit uit op die volk en sê: Dit is die bloed van die verbond wat die HERE met julle gesluit het op grond van al hierdie woorde.'

'n Uiters belangrike deel van hierdie verbond is God se belofte om in Israel se midde te woon. Dit word verskeie kere in die latere gedeeltes van die boek Eksodus beklemtoon $(25: 8 ; 29: 45 ; 33: 14-17 ; 40: 34-38)$. Hand aan hand met God se teenwoordigheid gaan die instruksies vir die ark en die tabernakel wat die plek is waar God sou woon (Eks 25-31, 35-40).

Levitikus is daarom die natuurlike vervolg op die tweede gedeelte van Eksodus, aangesien dit die vraag hoe Israel behoort te lewe wanneer God in hulle midde is, behandel. 
Levitikus gee die antwoord op hierdie vraag met praktiese riglyne vir die lewe saam met God in terme van die Mosaïese verbond. Na Israel se weiering om die beloofde land in te gaan (Num 13-14), laat God toe dat die ongehoorsame generasie sterf. Hy lei die volk dan terug na Kanaän toe. Voordat hulle ingaan, roep Hy hulle egter op tot verbondsvernuwing wat in Deuteronomium 5 beskryf word. Ons vind in fyn besonderhede die terme waaronder Israel in die beloofde land suksesvol sou lewe en deur God geseën sou word. Gehoorsaamheid aan die verbondsvoorskrifte sou seën bring en ongehoorsaamheid, vloek.

Dat die Tora onlosmaaklik verweef is met die verbond, is onbetwisbaar. Anders gestel: die Tora in sy geheel is die verbondsdokument van die ou verbond. Dit impliseer dat die Tora staan en val as 'n enkel entiteit.

\section{Die Tora: Oproep tot geloof en hartsverandering}

Die Tora het ten doel om God se mense innerlik te verander om gelykvormig aan Hom te wees (Krause 2015:5). Die hartsverandering (of tekort aan hartsverandering) kom op baie plekke in die Bybelteks na vore. Levitikus 19:17 maak dit byvoorbeeld duidelik dat geen Israeliet sy broeder in sy hart moes haat nie. Vervolgens praat Levitikus 26:41 oor die 'onbesnede hart' wat moet nederig word en Deuteronomium 4:29 roep die Israeliete op om die Here te soek met hulle hele hart en siel. Krause (2015:5) wys daarop dat die hele saak van die hart sekerlik die duidelikste na vore kom in die Shema van Deuteronomium 6:4. In die onmiddellike konteks identifiseer Moses die verbondsgod wat hulle uit slawerny bevry het (Deut 6:4). Hy is JAHWE en sy identifikasie stem ooreen met die proloog van die Dekaloog soos in Eksodus 20:2 waar JAHWE Homself bekendmaak voor Hy die gebooie gee. Net hierna word daar in Deuteronomium 6:5 duidelike aanduidings gevind dat ons nie te doen het met 'n blote preskriptiewe wet nie, aangesien hulle gehoorsaamheid nie bloot ekstern mag wees nie. Moses se verwysing na 'hart', 'siel' en 'krag' maak dit duidelik. Die hart word weer beklemtoon in Deuteronomium 6:7 en funksioneer as 'n soort parallelisme weens die herhaling. Uiteindelik beskryf Deuteronomium 6:8-9 die ooreenstemmende optrede van 'n werklik veranderde hart. Elkeen van hierdie frases wys op die uitwerking van die innerlike verandering.

Waar dit oor die hart gaan, kom geloof ter sprake. Reeds in die 1980s dui Schmitt (1982:170-189) aan dat die mees kenmerkende verskynsel in die redaksionele 'nate' van die Pentateug juis die konsekwente gebruik van die woord vir

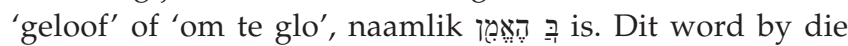
kritieke oorgangspunte tussen gedeeltes binne die hele korpus gevind. Hy onderskei die volgende sleuteltekse: Genesis 15:6, Eksodus 4:5, 14:31, Numeri 14:11 en 20:12. Kaiser (1996:194) meen dat Genesis 45:26 en Deuteronomium 1:32 en 9:23 ook bygevoeg kan word.

Die implikasie hiervan, soos Kaiser (1996:194) tereg aandui, is dat geloof aan die hart van die Tora lê. Dit is opvallend dat in elkeen van hierdie tekste geloof met die konsep van die 'hou van God se Tora' verbind is. Die teenoorgestelde is natuurlik ook waar: waar geloof afwesig is, lei dit tot rebellie teen God se wet. Die teologie van vertroue en geloof is dus bedoel om die teologie van bevele en bepalings te beheer.

Sailhamer (1991) maak in hierdie verband 'n belangrike opmerking:

It is as if the author of the Pentateuch has seized on the Abrahamic narratives as a way to explain the concept of 'keeping' the law. The author uses the life of Abraham, not Moses, to illustrate that one can fulfil the righteous requirements of the law. In choosing Abraham and not Moses, the author shows that 'keeping the law' means 'believing in God', just as Abraham believed God and was counted righteous (Gen 15:6). In effect the author of the Pentateuch says, 'Be like Abraham. Live a life of faith and it can be said that you are keeping the law'. (bl. 251)

In 'n uiters sinvolle en weldeurdagte bydrae oor die Pentateug wys Loader (2001:70-85) daarop dat, in die lig van die buigbaarheid van die term tema, die tema van die Pentateug in die term Tora uitgedruk kan word. Wát Tora is, word egter volgens Loader duidelik in die interverhouding tussen die motiewe van Goddelike voorsiening of 'evangelie', en gehoorsaamheid wat van mense verwag word: 'wet'. Hierdie tema word volgens hom dwarsdeur die Pentateug gevind. Anders gestel, die wetlike 'blokke' in die Pentateug is, soos daar nou reeds aanggedui is, geïnkorporeer in die narratiewe materiaal. Soos hy dit stel: 'a law-incorporating gospel is Torah' (Loader 2001:75).

Uit die voorafgaande argumentering het dit duidelik geword dat federale teologie se siening en hantering van die wet van Moses wel verskil van Ou-Testamentiese navorsingsbevindings oor die wet van Moses as Tora.

\section{Jesus Christus as die Tora}

Dat die Tora onlosmaaklik verweef is met verbond het nou duidelik uit die verf te voorskyn gekom. Daar kan selfs gesê word: die Tora is die verbond. Die verbondsformule wat soos 'n goue draad deur die Skrif loop, is 'Ek sal vir julle 'n God wees, julle moet my volk wees' (Rendtorff 1998:11). Hierdie formule is reeds implisiet aanwesig in Genesis 1-2 (König 1980:72-73).

König (1980:74-77) dui aan dat Jesus albei kante van hierdie God-mensverhouding, naamlik die verbondsformule vervul. Hy doen dit as die een wat God en mens is. Hy is nie net God vir ons nie, maar is ook in Homself God se ware volk met alles wat dit behels.

In Jesus word bevestig wat ons dwarsdeur die Ou Testament hoor en sien: dat God in hierdie verbondsverhouding werklik vir die mens is. Hy is nie sy skepping vyandig nie, Hy is ook nie neutraal teenoor sy skepping nie - Hy is vir sy skepping: 'So lief het God die wêreld gehad' - en 'wêreld' is vir Johannes die sondige mensdom. Soos die Tora as deskriptiewe wet iets van God, die outeur van die verbond vertel het, vertel Jesus ons wie God is. God vir ons. 
Dit is veral in die evangelie van Matteus dat Jesus pertinent geteken word as die een wat die rol van 'God se volk' oorneem en vervul. Dat Jesus die rol van Israel oorneem in Matteus se denke is duidelik wanneer Jesus uit Egipte geroep word (Matt 2:15), deur die water gaan (Matt 3) en in die woestyn versoek word soos Israel (Matt 4). Dat Jesus Satan uit Deuteronomium, die verbondsboek, antwoord, is natuurlik ook insiggewend (Poythress 1991:252; Van Bruggen 1999:55-57).

Die inhoud van die verbond 'Ek sal vir julle 'n God wees, en julle sal vir My 'n volk wees', is dus Jesus Christus en dit word (in albei dele) in en deur Jesus Christus vervul.

Dit is daarom nie vreemd dat verskeie teoloë die afgelope dekades Jesus self as die Tora beskou het nie. Daar is reeds na Barth se afwysing van die werkverbond verwys. Barth stel dit onomwonde dat die evangelie en die wet aan die begin van alle dinge (skepping) staan, want Jesus staan aan die begin as die eenheid van evangelie en gebod omdat Hy (in sy persoon) tegelyk God sowel as volmaak mens is - Hy is die sin en die grond van die verbond; ja, die verbond self, want Hy vervul die trou van God en die trou van die mense $(C D 4.1,56)$.

Moltmann (1967:193) skryf 10 jaar later: 'The central place of the Torah in late Jewish apocalyptic is ... taken by the person and the cross of Christ'. Gese (1981:89) kan na aanleiding van bybels-teologiese eksegese oor Jesus se verheerliking op die berg die volgende opmerking maak: 'The gospel writers could not present it more powerfully: Jesus himself is the Torah.'

Meer onlangs, en van deurslaggewende belang is die bydrae van N.T. Wright. Wright (2004) maak die volgende stelling:

\footnotetext{
... Torah was at one and the same time the charter of the people of God and the full and final revelation of God himself. If then Jesus has taken on this double role, it is no surprise to find him taking on precisely the role of Torah in Paul's understanding of the plan of the one God. (bl. 266)
}

In sy boek, The climax of the covenant wat in 2004 verskyn, wys Wright daarop dat Israel die posisie van Adam oorneem en dat die Jode bewus was dat hulle, as die nageslag van Abraham, op die een of ander wyse die herstel van die wêreld gaan bewerk in die lig van Genesis 12:1-3. Hulle was egter vas oortuig dat ' $n$ mens deel het aan hierdie Israel deur wie God die herstel gaan bring as die 'die werke van die wet' onderhou word. Dit beteken deur die besit van die Tora met alles wat dit behels en deur al die voorskrifte, taboes en feeste te onderhou, is en word jy deel van Abraham se nageslag - die mense wat die wêreld se herstel op een of ander wyse sal bewerk. Hulle het hulleself egter as tans in ballingskap gesien en verwag dat God 'n finale bevryding gaan bring waarin hulle die rol gaan speel as herstellers van die wêreld. Wat baie belangrik is, is die volgende: God se getrouheid aan sy verbond was op die spel. God kan nie sy verbond, sy beloftes aan Abraham en Israel verbreek nie. Daarmee saam is Israel se God natuurlik ook die Skepper van die wêreld (Wright 1996:23 e.v.).
Wat Paulus volgens Wright (2004:140) in die Romeine brief doen, is om te wys dat God getrou is aan sy verbond. God handhaaf sy geregtigheid. Paulus wys egter dat God nie meer die fisiese Israel gebruik om die wêreld te herstel en die verbond te bevestig nie, maar Jesus as die verteenwoordiger van Israel. In een van sy nuutste werke, The day the revolution began: Reconsiderng the meaning of Jesus's crucifixion, wat in 2016 verskyn, wys Wright daarop dat God in sy verbondsgetrouheid sy volk gestraf het en juis as gevolg daarvan vind die ballingskap plaas (bl. 304).

In Romeine 3:21 beteken die dikaiosyne theou volgens Wright ook 'God's covenant justice/faithfulness', en sondaars word vrylik verklaar as in die reg (dikaioumenoi) met Hom en dus as lede van die verbond ${ }^{1}$ deur die verlossing wat deur Jesus die plaasvervangende verteenwoordiger van Israel bewerk is. Alhoewel hierdie lees van dikaiosyne theou nie deur alle Romeinse kenners aanvaar word nie (Moo 2000:124-127), is dit moeilik om met geleerdes soos Dunn $(1988: 40-48,97)^{2}$ en Hays (1993:34-53) wat hierdie interpretasie onderskryf, te verskil.

Die skokkende vir die Jode moes volgens Wright (2004:146 e.v.; 2016:305) geleë gewees het in die feit dat 'n mens deel het aan hierdie 'Israel' (Jesus) nie deur die 'werke van die wet' (Tora) nie, maar deur die geloof in Hom wat gedoen het wat Israel nie kon doen nie: deur sy dood en opstanding. In en deur Jesus het die finale uittog of verlossing uit ballingskap aangebreek en kan die land (nuwe aarde, wêreld) verkry word. Verder, deur hierdie werk van Jesus word die Gees in die plek van die Tora verkry om die lewe te leef wat God behaag (Wright 2004:146 e.v.; 2016:305). Anders gestel, die 'verbondslewe' wat die Tora belowe het, maar nie kon gee nie (Rom 8:3), kon nou waarlik verkry word (v. 4)3: die 'lewe' wat verloor is by die skepping en nou finaal as 'ewige lewe' of opstandingslewe van die nuwe era geopenbaar word. Dat dít die gedagte by Paulus is, is nie net duidelik uit sy hele gedagtelyn in Romeine 8 nie, maar ook uit die aanduidings daarvan in 7:10 (die gebod wat die lewe moes gee) en Galasiërs 3:21 (as daar' $n$ wet gegee was wat die krag het om lewend te maak). Die Tora bring dus uiteindelik hierdie lewe, maar juis deurdat dit die sonde op Israel se verteenwoordiger, die Messias (Jesus), laai sodat God dit deur Hom kon straf. Juis deurdat die Tora op hierdie manier eintlik self verdoem word, kan

1. Wanneer hierdie uitleg aanvaar word, maak Romeine 4 natuurlik ook heeltemal sin Paulus moet nou wys wie is die verbondsfamilie waarvan ' $n$ mens deel word deur die geloof. 2. Dit is belangrik dat dit hier oor Dunn (1988) se verstaan van Romeine 3:21 gaan wat
nie beteken dat alles wat hy van die wet sê, onderskryf word nie. Dunn, soos Wright, nie beteken dat alles wat hy van die wet sê, onderskryf word nie. Dunn, soos Wright,
is natuurlik voorstanders van die sogenaamde New Perspective on Paul wat 'n paradigmaskuif in die hantering van Paulus en die wet verteenwoordig. Die dominante benadering tot Paulus het vir lank binne die raamwerk van sleutelreformatoriese konsepte gewerk. Teen die agtergrond van Luther se stryd met die 'pyne van die gewete' en 'n werke-georiënteerde Rooms-Katolisisme, is die regverdigmaking van die individu in die sentrum van Paulus se teologie geplaas. Sy opponente is as wettiese Jode of Judaïseerders gesien. In die nuwe benadering is daar ' $n$ groter waardering vir die sentraliteit van historiese en korporatiewe vrae in Paulus (Moo 1987.287). Ek onderskryf nie noodwendig Dunn en Wright se sienin van regverdigmaking of hulle siening van 'second temple Judaism' nie, maar is van regverdigmaking of hulle siening van 'second temple Judaism' nie, maar is oortuig dat hulle klem op die belangrkh van die verbond in God se plan met die wêreld sowel as die klem op die onlosmaaklike verband tussen wet en verbond van
groot waarde is en by hierdie studie se bevindings inpas.

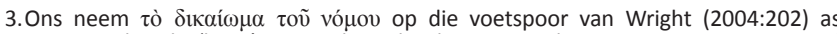
verwysend na die 'lewe' op grond van die algemene gedagtegang in Romeine 8 sowe as die verwysings in Romeine 7 en Galasiërs 3. 
lewe kom. Die Tora bereik dus die doel waarvoor dit gegee is op 'n paradoksale wyse in die geskiedenis.

Daarom kan daar onomwonde gesê word: die Toraverhouding vanaf die skepping is 'n afskaduwing van Jesus Christus; die Alfa en Omega, die Een met die oog op wie God geskep het (Kol 1:16); Die Een wat in geloof omhels moet word; Die Een wat hartsverandering bring. Anders gestel: God se skeppingsdoel is 'n Tora-verhouding. Aangesien Jesus Christus hierdie skeppingsdoel vir ons, in ons en met ons bereik het (König 1980:74-77), kan die Tora nie in dieselfde vorm die riglyn vir gelowiges bly onder die nuwe verbond nie, aangesien Jesus self nou die Tora is en sy Gees gee wat ons in staat stel om waarlik te leef as God se bondgenote.

\section{Enkele implikasies}

Wat is die implikasies van hierdie insigte vir die verstaan van die verhouding tussen God en mens, en die riglyn vir die Christen se dankbaarheidslewe?

\section{Godsbegrip}

Die etiese onder federalisme kan maklik gesien word as die gehoorsaamheid van wette - uitgevaardig deur 'n koue, onbeweeglike (Aristoteliese), harde God. Wanneer Wet deurgaans as Tora gesien word, word hierdie gevaar vermy. Vir geloofsekerheid kan so 'n beskouing 'n ingrypende impak hê wat weer 'n inpak het op geloofsverhoudings. Gelowiges hoef nie gedurig met die vinger op die pols te wonder of hulle 'n koue wetgewer (God) se voorskrifte genoegsaam onderhou het of nie. Hulle kan leef met die oortuiging dat hulle aanvaarbaar is op grond van Jesus - die Tora se werk in hulle plek. Voortvloeiend hieruit kan so 'n vernuwing van denke juis veroorsaak dat God se wil met vreugde deur die gemeente gehoorsaam word - diepsinnige gehoorsaamheid vanuit die hart van 'n verbondsgemeenskap wat opnuut besef dat hulle God geen vreemdeling is nie, maar hulle werklik in die liefde wat aan die kruis uitbasuin is, wil ontmoet (Van Hoozer 2005:391).

\section{Boeteprediking}

Wat sogenaamde boeteprediking (die prediking van die wet) as voorbereiding vir evangelie-prediking betref, kan daar in die lig van hierdie artikel beklemtoon word dat die wet nie as afsonderlike entiteit los van Christus gepredik moet word om op hierdie wyse mense na Jesus te dryf nie. Veel eerder moet Jesus met alles wat Hy is en behels, verkondig word. Jesus in wie Wet en Evangelie in volmaakte harmonie verkeer, moet dus as middel tot sonde-oortuiging sowel as die oplossing vir sonde verkondig word.

\section{Regverdigmaking deur die geloof}

In die lig van die bevinding van hierdie artikel kan die prediking van regverdigmaking nie gepreek word asof Jesus verskillende morele gebooie in gelowiges se plek nagekom het om só hulle geregtigheid voor God verdien nie. Sulke prediking lei onbewustelik tot die pastorale probleem dat gelowiges steeds hulle verhouding met God as verdienstelik sien en beleef, aangesien Christus se gehoorsaamheid aan 'gebooie' op die mens oorgedra is en hy of sy dan sekerlik nou hierdie tipe gehoorsaamheid moet handhaaf. Die gepaardgaande gevolge van so 'n siening kan ongetwyfeld by die sensitiewe gelowige lei tot probleme wat heilsekerheid betref. Veel eerder moet daar, soos aangedui, noukeurig met gedeeltes soos Romeine 6 omgegaan word. Hier kan baie geleer word by Wright (1980:13-26). Daar moet aangedui word dat Jesus (die troue Bondgenoot) gesterf het as verbondsverbreker (my verbondsverbreking) en weer opgestaan het as onderhouer van die verbond. Soos Van Hoozer (2005:387) dit stel: 'Jesus se dood is die klimaks van die verbondsdrama.' Dit is deur gelowiges se verbondenheid met Hom (deur die geloof) dat hulle nou voor God as regverdiges staan.

\section{Die riglyn vir die Christen se dankbaarheidslewe}

Federale teologie gaan as 't ware na die Christusgebeure vir genade, maar keer terug na Moses vir etiek. Dit sê in werklikheid dat Christus ons geloof moet struktureer, maar Moses is ons etiek. Daar vind dus 'n skeiding plaas in die dinamiese verhouding tussen die historiese verlossingsgebeure en die etiek wat daaruit voortvloei.

Die Nuwe Testament stuur nie die Gees-gedoopte gemeenskap terug na Moses om hulle plig te leer nie. Nêrens word die náPinkster gemeenskap vermaan om die Tora as riglyn vir hulle lewens te bestudeer nie. Deurgaans in sy briewe redeneer Paulus vanaf die evangelie-gebeure na etiek. Hy wys hoe die verlossingshandeling in Christus moet bepaal hoe ons ons in alle menslike verhoudings moet gedra. Byvoorbeeld:

- Wanneer Paulus gekonfronteer word met die probleem van seksuele immoraliteit in Korinte, verdoem hy nie sulke gedrag op die basis van die Tora nie. Hy redeneer vanuit die feit dat ons eenheid met Christus beteken dat ons liggame deel van Hom is (1 Kor 6:15-20).

- Wanneer Petrus en sy metgeselle fouteer in Antiochië en in die openbaar tereggewys moet word, verdoem Paulus hulle gedrag ook nie op die basis van die Tora nie. Hy staan hulle teë op grond van die feit dat 'hulle nie reguit loop volgens die waarheid van die evangelie nie' (Gal 2:14).

- Vir Paulus is verkeerde gedrag alles 'wat ... met die gesonde leer in stryd is, volgens die evangelie van die heerlikheid van die salige God wat aan my toevertrou is' (2 Tim 1:10, 11).

- Vir hom is dit die 'genade van God' en nie die Tora nie wat verlossing bring, sowel as ons leer om nee te sê vir die goddeloosheid en om:

wêreldse begeerlikhede te verloën, ingetoë en regverdig en vroom in die teenswoordige wêreld te lewe, terwyl ons die salige hoop en die verskyning van die heerlikheid verwag van die grote God en ons Verlosser, Jesus Christus. (Tit 2:11-13)

Paulus haal die Ou-Testamentiese gebooie slegs in drie of vier geïsoleerde gevalle aan. Waar hy dit wel doen, is dit nie 
die basis van sy etiese appèl nie, maar 'n sekondêre appèl en selfs dán gebruik hy die Tora met groot profetiese vryheid (kyk 1 Kor 9:9). 'n Stelling uit die Tora het nie vir Paulus dieselfde absolute outoriteit as wat dit vir Judaïsme het nie. Rosner (2013:88) wys daarop dat Paulus wel na Christene verwys wat die wet 'vervul', maar nooit sê dat Christene die wet moet 'hou' of 'gehoorsaam' nie. Gelowiges gehoorsaam die evangelie.

Aangesien die Tora ons tot heiligheid en dankbaarheid teenoor God, en 'n lewe van geloof en liefde oproep, leef die gees van die ou wet steeds voort onder die nuwe bedeling. Die tydlose etiese beginsels in die Tora leef voort onder Jesus, die Tora. Op hierdie wyse kan die Tora soos 'n emeritusprofessor steeds van waarde wees in die instruksie met betrekking tot geregtigheid. Ons kan egter nie meer sê dat iets reg of verkeerd is net omdat dit in die Tora is nie. As 'n 'verbond' (Deut 4:13), het die Tora tot 'n einde gekom (Heb 8:13), aangesien daardie verbond met die superieure bediening van die Gees vervang is (2 Kor 3:4-11).

Die gewete van selfs 'n nie-Christen sal baie gou die tydlose, etiese beginsels in byvoorbeeld Levitikus 19 herken op grond van algemene openbaring.

Wat die ander wette betref, moet ons dit ondersoek met die evangelie van die Nuwe Testament. Anders gestel: ons moet dit in die lig van Jesus, die Tora meet.

\section{Slotsom}

Na afloop van hierdie studie kan daar dan tot die volgende slotsom gekom word: 'n verbondsmatige teologiese beskouing van die Tora moet Jesus Christus as God se skeppingsdoel sien en as sodanig die inhoud van die verbond regdeur die Bybel; dus dat Hy, na sy menswording, die rol van die Tora vir die gelowige vervul.

Dit is gepas om hierdie studie rondom 'n nuwe verstaan van die Tora aan gereformeerdes te rig met die pleidooi van iemand vir wie Verbondsteologie na aan die hart gelê het:

It would not be ... in the interests of theological conservation or theological progress to think that the covenant theology is in all respects definitive and that there is no further need for correction, modification and expansion. Theology must always be undergoing reformation. The human understanding is imperfect ... there always remains the need for correction and reconstruction so that the structure may be brought into closer approximation to the Scripture ... It appears to me that the covenant theology ... needs recasting (Murray 1954:4-5).

AD MAIOREM GLORIAM DEI

\section{Erkenning \\ Mededingende belange}

Die outeur verklaar dat hy geen finansiële of persoonlike verbintenis het met enige party wat hom nadelig of voordelig kon beïnloed het in die skryf van hierdie artikel nie.

\section{Literatuurverwysings}

Barth, K., 1956, Church dogmatics, T\&T Clark, Edinburgh.

Bavinck, H., 1922, The sacrifice of praise, Louis Kregel, Grand Rapids, MI.

Bell, M.C., 1985, Calvin and Scottish theology: The doctrine of assurance, Handsel, Edinburg.

Berkouwer, G.C., 1971, Sin, Eerdmans, Grand Rapids, MI.

Brown, F., Driver, S.R. \& Briggs, C.A., 1966, Hebrew and English lexicon of the Old Testament, Claredon, Oxford.

Calvyn, J., 1984, Institusie van die Christelike godsdiens, Calvyn Jubileum Boekefonds, Potchefstroom.

$C D$, see Barth 1956

Dumbrell, W.J., 1984, Covenant and creation: A theology of the Old Testament covenants, Paternoster, London.

Dunn, J.D.G., 1988, Word biblical commentary: Romans 1-8, Thomas Nelson, Nashville, TN.

Fenner, D., 1613, The sacred doctrine of divinitie, Claredon, Oxford.

Forde, G.O., 1997, On being a theologian of the cross: Reflections on Luther's Heidelberg disputation, 1518, Eerdmans, Grand Rapids, MI.

Gese, H., 1981, 'The Law', in H. Gese (ed.), Essays on biblical theology, pp. 60-92, Augsburg Publishing House, Minneapolis, MN.

Hays, D.P., 2001, 'Applying the Old Testament law today', Bibliotheca Sacra 158, 21-35.

Hays, R.B., 1993, Echoes of scripture in the letters of Paul, Yale University Press, Yale University.

Hesselink, I.J., 1997, Calvin's first catechism: A commentary, John Knox, Louisville, KY. Inst., kyk Calvyn 1984

Jonker, W., 1989, Uit vrye guns alleen, NG-Kerkboekhandel, Pretoria.

Kaiser, W.C., 1996, 'The law as God's gracious guidance for the promotion of holiness' in G.L. Bahnsen, W.C. Kaiser, D.J. Moo, W.G. Strickland \& W.A. VanGemeren (eds.) Five views on law and Gospel, pp. 177-200, Zondervan, Grand Rapids, MI.

Karlberg, M.W., 1980, 'Reformed interpretation of the mosaic covenant', Westminster Theological Journal 43, 1-53.

Koehler, L. \& Baumgartner, W., 1958, Lexicon in Veteris Testamenti libros, Brill, Leiden.

König, A., 1969, 'Jesus Christus die eskatos: Die fundering en struktuur van die eskatologie as teleologiese Christologie', DD-Proefskrif, Universiteit van Pretoria.

König, A., 1980, Jesus die laaste, 2 de uitg., NG-Kerkboekhandel, Pretoria.

Krause, J.S., 2015, 'The Grace of God in the Law of Moses: A Second Look at Israel's Written Code', Fidei et Veritatis: The Liberty University Journal of Graduate Research 1(2), 1-18.

Le Roux, P.J., 1991, 'Verbond en gemeente: Die betekenis van verbond vir kerk en kosmos', DD-proefskrif, UNISA.

Loader, J.A., 2001, 'Law and Gospel in the Pentateuch organisation', Hervormde Teologiese Studies 57, 70-85. https://doi.org/10.4102/hts.v57i1/2.1844

Luther, M., 1856, Ausführliche Erkläring der Epistel an die Galater, Verlag Gustav Schlawitz, Böhlaus Nachfolger.

Luther, M., 1892, Martin Luthers Werke: Kritische Gesammtausgabe, Weimarer Ausgabe, Böhlaus Nachfolger.

Luther, M., 1958, 'Works', in J. Pelikan \& H.T. Lehmann (eds.), Luther's Works, English transl., American edn., Fortress, Philadelphia, PA.

LW, kyk Luther 1958

Mann, W., 1988, The book of the torah. The narrative integrity of the Pentatech, John Knox, Louisville, KY.

McCoy, C.S. \& Baker, J.W., 1991, Fountainhead of Federalism: Heinrich Bullinger and the covenental tradition, John Knox, Louisville, KY.

McNeil, S., 1946, 'Natural law in the theology of the Reformers', Journal of Religion, 26, 1-20.

Moltmann, J., 1967, Theology of hope, Harper \& Row, New York.

Moo, D., 1987, 'Paul and the law in the last ten years', Scottish Journal of Theology 40 , 287-307. https://doi.org/10.1017/S0036930600017579

Moo, D., 2000, Romans: NIV application commentary, Zondervan, Grand Rapids, MI.

Murray, J., 1954, The covenant of grace, Tyndale, London.

Murray, J., 1977, Collected writings II, Banner of Truth, Edinburg.

Poythress, V., 1991, The shadow of Christ in the law of Moses, Presbyterian \& Reformed Philipsburg, New Jersey.

Rendtorff, R., 1998, The covenant formula: An exegetical and theological investigation, T\&T Clark, Edinburgh, Scotland.

Rolston, H., 1972, John Calvin versus the Westminster Confession: Holmes Rolston III calls on the Reformer himself to refute the oppressive legalism of the Calvinists and to free $20^{\text {th }}$ century man for responsible life with a gracious God, John Knox Virginia.

Rosner, B.S., 2013, Paul and the law: Keeping the commandments of God, InterVarsity, Downers Grove, IL. (New Studies in Biblical Theology, 31). 
Sailhamer, J.H., 1991, 'The Mosaic law and the theology of the Pentateuch', Westminster Theogical Journal 53, 241-261.

Schmitt, H., 1982, 'Redaktion des Pentateuch im Geiste der Prophetie', Vetus Testamentum 32, 170-189. https://doi.org/10.1163/156853382X00045

Torrance, J.B., 1994, 'The concept of federal theology: Was Calvin a federal theologian?', in W.H. Neuser (ed.), Calvinus sacrae scriptura professor; Calvin as confessor of Holy, Scripture, pp. 19-33, Eerdmans, Grand Rapids, MI.

Van Bruggen, J., 1999, Matteus: Het evangelie voor Israël, Kok, Kampen.

Van Hoozer, D., 2005, Drama of doctrine: A canonical linguistic approach to Christian theology, Westminster John Knox Press, Louisville, KY.

VanGemeren, W.A., 1996, 'The law is the perfection of righteousness in Jesus Christ: A reformed perspective', in G.L. Bahnsen, W.C. Kaiser, D.J. Moo, W.G. Strickland \& W.A. VanGemeren (eds.), Five views on law and Gospel, pp. 13-59, Zondervan, Grand Rapids, MI.

WA, kyk Luther 1892

WCF, kyk Westminster Confession of Faith 2010
Weir, D.A., 1990, The origins of the federal theology in sixteenteenth-century reformation thought, Claredon, Oxford.

Wenham, G., 2003, Exploring the Old Testament:The Pentateuch, vol. 1, SPCK, Great Britain.

Westminster Confession of Faith, 2010, The Westminster confession of faith and Catechisms in modern English, Presbyterian and Reformed Publishing Company, Livonia, MI.

Wright, J.H., 1983, An eye for an eye: The place of Old Testament ethics today, IVP, Dowers Grove, IL.

Wright, N.T, 1980, 'Justification: The Biblical basis and its relevance for contemporary evangelicalism', in G. Reid \& J. Gavin (ed.), The great acquittal: Justification by faith and current Christian thought, pp. 13-26, Fortress, Minneapolis, MN.

Wright, N.T., 1996, Jesus and the victory of God, Fortress, Minneapolis.

Wright, N.T., 2004, The climax of the covenant, Fortress, Minneapolis, MN.

Wright, N.T., 2016, The day the revolution began: Reconsidering the meaning of Jesus's crucifixion, HarperOne, New York. 